\title{
MATERIALS COMPATTBILITY AND LUBRICANTS RESEARCH ON CFC-REFRIGERANT SUBSTITUTES
}

\author{
Quarterly MCLR.Program \\ Status Report
}

1 October 1995 - 31 December 1995

Steven R. Szymurski

\begin{abstract}
Air-Conditioning and Refrigeration
Technology Institute, Inc.

4301 North Fairfax Drive, Suite 425

Arlington, Virginia 22203
\end{abstract}

February 1996

\author{
Prepared for \\ The U.S. DEPARTMENT OF ENERGY \\ Office of Building Technology \\ Grant Number DE-FG02-91CE23810
}

This program is supported, in part, by U.S. Department of Eners errot number DE-FG02-91CE23810: Materials Compatibility and Lubricants Research (MCLR) on CFC-Refrigerant Substitutes. Fedend funding rupporting this program constitures $93.57 \%$ of allowable costs. Funding from non-government sources supporting this progerm consits $6.43 \%$ of allowable costs, and significant in-kind contributions from the air-conditioning and refrigeration industry.

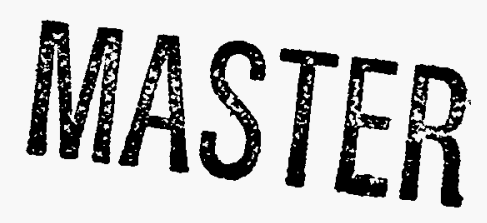




\title{
MATERIALS COMPATIBILITY AND LUBRICANTS RESEARCH ON CFC-REFRIGERANT SUBSTITUTES
}

\section{Quarterly MCLR Program Status Report}

\author{
1 October 1995 - 31 December 1995
}

\section{QUARTERLY PROGRAM OBJECTIVES}

- Complete contract negotiations for the following project:

Project 665-53200: Study of Foaming Characteristics.

- Finalize the remaining Phase IV work statements and solicit the following projects:

Project 665-52401: Risk Assessments of A2 Refrigerants in a Residential Split System Heat Pump.

Project 665-533001: Flammability Risk Analysis of HFC-245ca in Chillers.

- Continue development of project work statements for remainder of the Phase IV projects and Phase V projects. 


\section{PROGRAM ACCOMPLISHMENTS}

Appendix A contains a detailed program schedule. Progress toward achieving the quarterly objectives are summarized below.

\section{Contracts for Phase IV Research Projects}

During the fourth quarter 1995, ARTI negotiated a contract for the following research project:

Project 665-53200: Study of Foaming Characteristics. The University of Florida signed the contract on 26 October 1995. The effective start date of the project is 19 October 1995.

\section{Phase IV Project Work Statements}

The MCLR Advisory Committee continued to develop work statements for the following research projects:

Project 665-52401: Risk Assessment of A2 Refrigerants in a Split System Residential Heat Pump. The MCLR Advisory Committee reviewed the draft work statement at its 7 December 1995 meeting and directed additional modifications:

Project 665-53301: Flammability Risk Analysis for HFC-245ca in Chillers. The Committee reviewed the draft work statement at its 7 December 1995 meeting and decided to delay the project for six-months, pending UL resolution of revisions to UL. 2182 .

Project 665-50400: Stability and Materials Compatibility of New Refrigerants and Lubricants. (Work statement development is tabled pending additional toxicity and performance assessments are available to assess the potential use of proposed new alterative refrigerants.)

Project 665-51200: Miscibility, Solubility and Viscosity Measurements of New Refrigerants and Lubricants. (Work statement development is tabled until additional toxicity information and performance assessments are available to assess the potential use of proposed new alternative refrigerants.) 


\section{Phase V Project Work Statements}

The MCLR Advisory Committee continued to develop the following Phase V work statements:

Project 670-54500: Use of High Glide Refrigerants. The MCLR Advisory Committee approved, pending DOE Phase V approval, a work statement proposed by NIST to develop a computer simulation model for predicting the impact of air-side mal-distribution of air flow on the performance of finned-tube evaporators with R-22 and R-407C.

Project 670-54300: Determine Equilibrium Point Dryness Curves and Water Capacity of Desiccants with Alternative Refrigerants. The MCLR Advisory Committee reviewed a draft work statement and directed the project monitoring subgroup to revise it.

Project 670-54100: Moisture Distribution in Refrigerant, POE, and Desiccant Driers. The MCLR Advisory Committee reviewed a draft work statement and directed the project monitoring subgroup to revise it.

Project 670-54200: Effects of Temperature on Desiccant Catalysis of Refrigerant-Lubricant Decomposition. The MCLR Advisory Committee reviewed a draft work statement and directed that it be revised and balloted by mail.

Project 670-54400: Criteria for Replacement of POE Lubricants Due to Degradation. The MCLR Advisory Committee reviewed a draft work statement and decided to table further action on it pending a decision from the AREP Technical Committee on whether or not to conduct the project under that program.

\section{Program Management Activities}

\section{Contract Modifications}

Two research subcontracts were modified during the fourth quarter 1995.

Project 660-52600: Effects of Lubricant Additives. On 26 December 1995 the contract was modified to require the subcontractor to submit monthly progress status reports with invoices. This modification was made at no additional cost to the contract.

Project 660-54000: Infrared Analysis of Refrigerant Blends. On 19 October 1995, a no-cost extension was approved extending the project through 31 December 1995. On 21 December 1995, a second no-cost extension was granted extending the project through 30 March 1995. 


\section{On-site Technical Reviews}

One on-site technical review was conducted during the fourth quarter of 1995.

Project 660-52000 Compatibility of Manufacturing Process Fluids with HFC Refrigerants and Ester Lubricants. On 2 November 1995, the project monitoring subgroup conducted an on-site technical review at Imagination Resources, Inc. in Dublin, OH.

\section{Status of Final Reports on MCLR Projects}

During the fourth quarter 1995, the MCLR Advisory Committee and ARTI reviewed or approved the following final reports:

DOE/CE/23810-41 Final Report, Project 655-51500: Accelerated Screening Methods for Chemical and Thermal Stability, Part 2. The report was approved on 11 December 1995.

DOE/CE/23810-50 Final Report, Project 660-52400: Methods Development for Measuring and Classifying Flammability/Combustibility of Refrigerants. The report was approved and distributed on 18 October 1995. (RDB5A18)

DOE/CE/23810-67 Final Report, Project 665-53300: Evaluation of HFC-245ca as a Low Pressure Refrigerant. The draft report was received 24 December 1995 and distributed to the MCLR Advisory Committee for review.

\section{Technical Presentations}

During the fourth quarter 1995, ARTI staff coordinated technical paper submissions and participation of subcontracted researchers in the 1995 International CFC and Halon Alternatives Conference held 23 - 25 October 1995 in Washington, DC, and in the 1996 ASHRAE Winter Meeting scheduled for February 1996 in Atlanta, GA. The following presentations were made during the quarter:

Presented and published in the Proceedings of the International CFC and Halon Alternatives Conference (Washington, DC, 21 - 23 Oct 95), Alliance for Responsible Atmospheric Policy, 1995:

H. Harvey Michels (United Technologies Research Center): Solubility Modeling of Refrigerant/Lubricant Mixtures, pages 49-58. 
Jay Field (Spauschus Associates, Inc.): Sealed Tube Comparisons of the Compatibility of Desiccants with Refrigerants and Lubricants, pages 149-158.

Robert Doerr (The Trane Company): Compatibility of Refrigerants and Lubricants with Motor Materials Under Retrofit Conditions, pages 159-168.

James M. Calm (Engineering Consultant): Refrigerant and Lubricants - Data for Screening and Application, pages 169-178.

\section{OBJECTIVES FOR FIRST QUARTER OF CALENDAR YEAR 1996}

- Finalize work statements and solicit the following Phase IV projects:

Project 665-52401: Risk Assessments of A2 Refrigerants in a Residential Split System Heat Pump.

- Continue development of work statements for Phase $\mathrm{V}$ projects and solicit projects upon DOE approval of Phase V:

Project 670-54500: Use of High Glide Refrigerants.

Project 670-54300: Determine Equilibrium Point Dryness Curves and Water Capacity of Desiccants with Alternative Refrigerants.

Project 670-54100: Moisture Distribution in Refrigerant, POE, and Desiccant Driers.

Project 670-54200: Effects of Temperature on Desiccant Catalysis of Refrigerant-Lubricant Decomposition. 


\section{PROGRAM COSTS}

Phase IV of the MCLR program was approved on 15 September 1994. This approval increased the program budget by $\$ 3,416,493$ ( $\$ 3,190,00$ from DOE funding and $\$ 226,493$ from industry direct cost sharing). However, obligation authority was released for only $\$ 1,590,000$ of the $\$ 3,190,000$ DOE funding. On 14 February 1995, DOE released obligation authority for an additional $\$ 1,400,000$, raising the cumulative obligation authority for DOE funding to $\$ 9,033,000$. The obligation authority for the remaining $\$ 200,000$ of DOE funding is expected later this year. The budget figures below include the entire approved budget. ARTI has previously reprogrammed several management budget subcategories: $\$ 10,000$ was reprogrammed from "Consultants" to "Travel" and $\$ 5,012$ was reprogrammed from "Consultants" to "Other Direct". These reprogrammed funds are reflected in the revised budget below.

As of 31 December 1995

\begin{tabular}{||l|r|r|r|r|r||}
\hline CATEGORY & $\begin{array}{r}\text { ORIGINAL } \\
\text { BUDGET }\end{array}$ & $\begin{array}{r}\text { REVISED } \\
\text { BUDGET }\end{array}$ & $\begin{array}{c}\text { SPENT } \\
\text { TO DATE }\end{array}$ & $\begin{array}{c}\text { BUDGET } \\
\text { TO DATE* }\end{array}$ & $\begin{array}{r}\text { UNDER } \\
\text { (OVER) } \\
\text { SPENT }\end{array}$ \\
\hline Salaries & $\$ 752,017$ & $\$ 752,017$ & $\$ 611,584.35$ & $\$ 680,279.00$ & $11.1 \%$ \\
\hline Travel & $\$ 91,093$ & $\$ 96,105$ & $\$ 70,798.91$ & $\$ 89,332.50$ & $20.7 \%$ \\
\hline Consultant & $\$ 31,200$ & $\$ 16,188$ & $\$ 5,801.51$ & $\$ 16,188.00$ & $64.2 \%$ \\
\hline Other Direct & $\$ 66,962$ & $\$ 76,962$ & $\$ 67,004.65$ & $\$ 69,758.25$ & $3.9 \%$ \\
\hline $\begin{array}{l}\text { Indirect } \\
\text { MGMT } \\
\text { TOTAL }\end{array}$ & $\$ 682,524$ & $\$ 682,524$ & $\$ 553,474.14$ & $\$ 617,088.75$ & $10.0 \%$ \\
\hline RESEARCH & $\$ 1,623,796$ & $\$ 1,623,79.6$ & $\$ 1,308,663.56$ & $\$ 1,472,647.00$ & $11.1 \%$ \\
\hline $\begin{array}{l}\text { GRANT } \\
\text { TOTAL }\end{array}$ & $\$ 9,244,095$ & $\$ 8,244,095$ & $\$ 5,833,814.01$ & $\$ 7,114,059.13$ & $18.0 \%$ \\
\hline \hline
\end{tabular}

* Budget to date is based on a straight line projection of the budget over the period of the grant. 


\section{APPENDIX A}

MATERIALS COMPATIBILITY AND LUBRICANTS RESEARCH

Detailed Program Schedule 

Materials Compatibility \& Lubricants Research (MCLR) Program Status DOE Gront Number DE-FGOQ-D1CE23910

AREA OF INTEREST

Propetmit

\section{MANAEEMENT}

Prave!

Phases III
Prase N

DATA COLLCTION \& DISSEMINATION

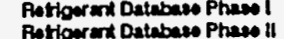

Rothow wart Dulubaw Phase il

Rutigerent Toxdty sumey

Symposta \& Corteronsoses

PEFRGERNNTRUERTCANT PROPERTES Trumophy deal Propertios (Ras, 123, 124, \&

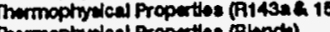
Thermephydeal Propertibe (Phew in

Chomeal a mormal stublity

Preme 1)

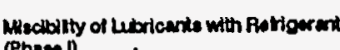

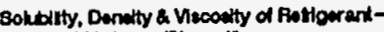
Lubricand Mbaturos (Pheso in

Vecoutty, Donedty a ass solubity of

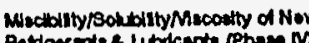

(Phas M

Thoorotcal Evalualone of R-22 Alcornatvo

EHDEnhancomorx of in-Tubo Bollng

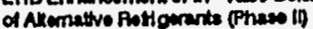

Frectoreton of Puttowart Blande

Flempriblity Mosucromorts

Lubricenteroustion

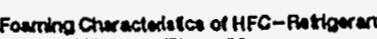

Evaluation of MFC-24sca as a Low Prozero Rotlowerat (Pheve in)

Flemmenality Fits Aneysts of HFC-245ce

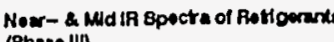

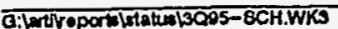

Page A-1

as of: 30 September 1985 - RFP Thectrical Roviow (Complotodiftarno of P/r Roport (Complitodpherriod

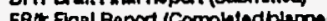
FFe" Final Beport Deterbeted

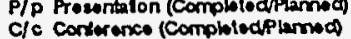


Materials Compatibility \& Lubricants Research (MCLA) Program Status

DOE Grant Number DE-FG02-81CE23010

AREA OF INTEREST

Propet Tite

MATERINLS COMPATIBIUTY Compelloilty with Motor Mated ak (Phaw i)

Compastilty of Motor Matedala lor Rotrolt (Phaso iI)

Compestbilty with Elestomion

Compatbilty with Endrowing Plestice

(Phase II)

Compentiblty wth Desiccents Compeldolty wth Menuchacturino Procoses Fuld

Compaltility with Proctucts of Motor Bumous (Phase 11)

Compalblity with Lubitcart Addtivos

Otad itymatiak Compatbilty of Now

METHODS DEVELOPIENT

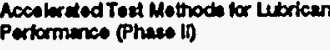

Accoserked Tout Mothods for Prodettion the Ltho of Motor Matertals (Phene 1)

\section{Accolureded Tost Mothock for Chomlcal}

a. Thermal Btablty (Ptreat in

Mothoch Doweloponont for Flermmedityl

Combuetiblity of fottooranto (Phawo II)

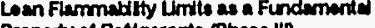

Proporty of fintlowerts (Phase III)

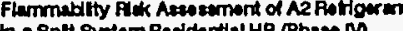

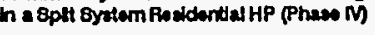

Fhumbro \& Cwan-ocat Methode (Phaseo III)

contactor 1

cortractor 2

Syatom Contentinent Lovets

(Phese M)

Mothode Documontaton a

Standerats Doveloprivent

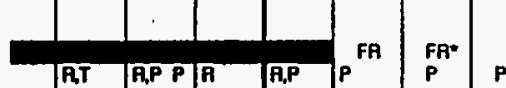

1001 1002 1002 (1003

TFM M J JABOND J003

1004

J005

${ }_{P}^{F F^{*}} P$

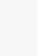

$p$

-

.

-
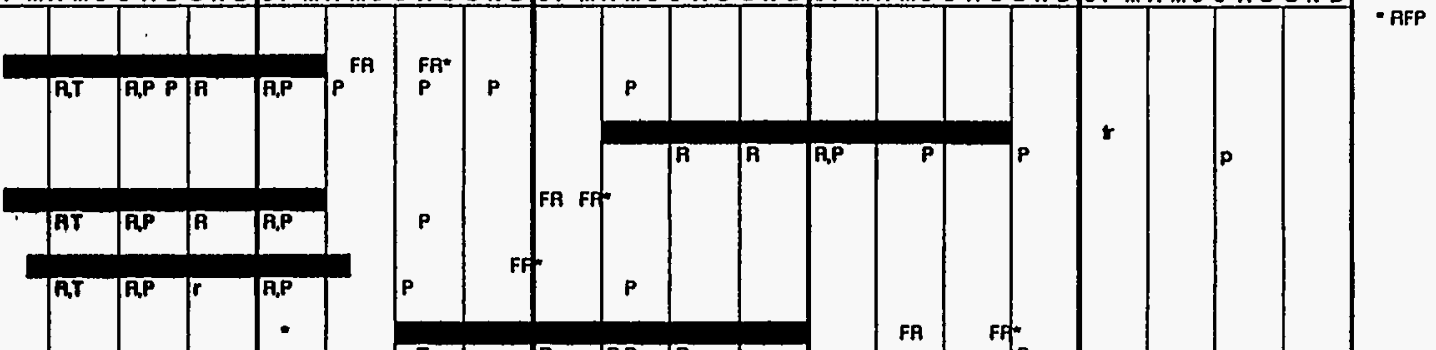

ar $r$,

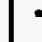

$P$

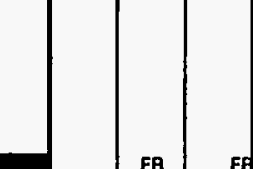

(

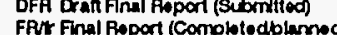

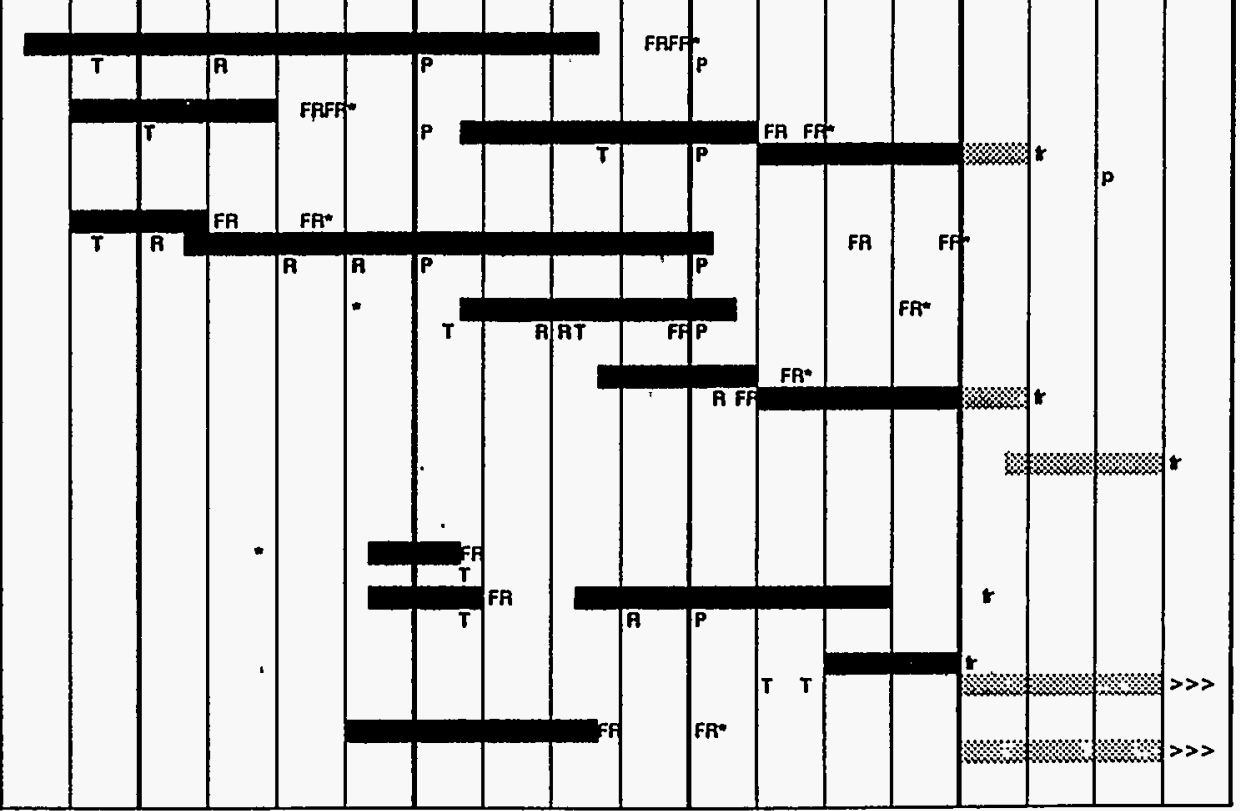

FF" Final Report Dlembuted

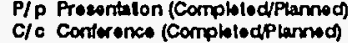

Page A-2

as of: 30 Soptember 1895

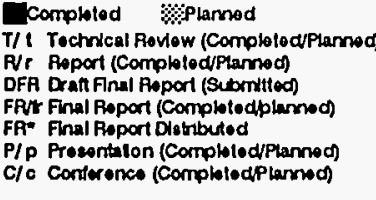




\section{DOE Grant Approvals \& Modifications}

MCLR program grant awarded: 30 Sep 91

Original end-date: $30 \mathrm{Mar} 93$

Approved budget:

$\$ 2,016,000$ DOE Share

$\$ 130,000$ ARTI Share

$\$ 2,146,000$ Total

Phase II supplemental request (Amend A001) awarded: 30 Sep 92

Revised end-date: 30 Sep 94

Revised cumulative budget:

$\begin{aligned} \$ 4,143,000 & \text { DOE Share } \\ \$ 280,000 & \text { ARTI Share } \\ \$ 4,423,000 & \text { Total }\end{aligned}$

Phase III supplemental request (Amend A002) awarded: 28 Sep 93

Revised end-date: 30 Sep 95

Revised cumulative budget:

$\$ 6,043,000$ DOE Share

$\$ 408,398$ ARTI Share

$\$ 6,451,398$ Total

Supplemental agreement for the exclusion of proprietary data signed: 11 Mar 94.

Phase IV supplement request (Amend A003) awarded: 15 Sep 94

Revised end-date: 30 Sep 96

Revised cumulative budget:

$\$ 9,233,000$ DOE Share*

$\$ 634,861$ ARTI Share

$\$ 9,867,891$ Total

* Only $\$ 7,633,000$ of the cumulative DOE share was initially obligated.

Phase IV FY95 funding obligation authority (Amend A004) granted: 14 Feb 95

Revised cumulative DOE obligation authority: $\$ 9,033,000$ DOE Share Obligated

** Obligation of the remaining $\$ 200,000$ for the cumulative DOE share is expected later this year. 


\section{DOE Program Reviews}

5 Nov $91 @$ DOE Chicago Field Office, Argonne, II

3 Feb 93 @ DOE, Washington, DC

11 Aug 93 @ DOE. Washington, DC

8 Feb $94 @$ DOE, Washington, DC

$15 \mathrm{Mar} 94$ Certification form concerning research involving human subjects forwarded to DOE Human Experimentation Task Force, Chicago Operations Office.

17 Mar 94 @ ARI with new DOE Program Manager

\section{MCLR Advisory Committee Meetings}

7 Nov 91 @ ARI, Arlington, VA

13 Feb $92 @$ ARI, Arlington, VA

14 May $92 @$ ARI, Arlington, VA

2 Oct $92 @$ ARI, Arlington, VA

$15 \mathrm{Jan} 93$ @ ARI, Arlington, VA

11 Mar 93 @ ARI, Arlington, VA

10 Jun $93 @$ ARI, Arlington, VA

14 Sep 93 @ ARI, Arlington, VA

8-9 Nov $93 @$ NIST, Gaithersburg, MD

10 Feb $94 @$ ARI, Arlington, VA

3 May 94 @ ARI, Arlington, VA

2 Aug 94 @ ARI, Arlington, VA

11 Oct 94 @ ARI, Arlington, VA

16 Feb 95 @ ARI, Arlington, VA

18 May 95 ARI, Arlington, VA

6 Sep $95 @$ ARI, Arlington, VA

7 Dec 95 @ ARI, Arlington, VA

\section{Invention Disclosures}

Case No. S-80,198 Conceptual Design of an Improved Stator Simulator Device for Testing of Alternative Refrigerant/Lubricant Mixtures.

1 Nov 93 Invention disclosure forwarded to DOE.

22 Nov 93 DOE case number assigned.

22 Jun 94 ARTI conveyed title to DOE.

$11 \mathrm{Jul} 94$ DOE dropped case due to insufficient potential use and defensive publication.

Case No. S-81,177 Device for Removing Residual Mineral Oil in Retrofit Refrigeration Systems.

$10 \mathrm{Mar} 94$ Invention disclosure forwarded to DOE.

21 Mar 94 DOE case number assigned.

20 Sep 94 Subcontractor elects to retain title. 
MCLR Program Status

as of 31 December 1995

\section{Cash Advances and Reimbursements}

27 Jan 92

$6 \operatorname{Mar} 92$

$18 \operatorname{Mar} 92$

3 Apr 92

27 May 92

27 May 92

26 Jun 92

10 Aug 92

22 Sep 92

22 Oct 92

30 Nov 92

14 Dec 92

12 Feb 93

12 Feb 93

23 Mar 93

15 Apr 93

19 Jul 93

$22 \operatorname{Sep} 93$

18 Oct 93

15 Nov 93

21 Dec 93

3 Feb 94

18 Mar 94

10 May 94

27 May 94

14 Jun 94

$11 \mathrm{Jul} 94$

11 Aug 94

6 Sep 94

4 Oct 94

21 Nov 94

17 Jan 95

$7 \mathrm{Feb} 95$

9 Mar 95

25 Apr 95

27 Jul 95

18 Sep 95

3 Oct 95

2 Nov 95

14 Nov 95
Received Partial Payment \#01

Received Partial Payment \#02

Received Partial Payment \#03

Received Partial Payment \#04

Received Partial Payment \#05

Received Partial Payment \#06

Received Partial Payment \#07

(includes pre-award costs)

Received Partial Payment \#08

Received Partial Payment \#09

Received Partial Payment \#10

Received Partial Payment \#11

(includes Phase II pre-award costs)

Received Partial Payment \#12

Received Partial Payment \#13

Received Partial Payment \#14

Received Partial Payment \#15

Received Partial Payment \#16

Received Partial Payment \#17

Received Partial Payment \#18

Received Partial Payment \#19

Received Partial Payment $\$ 20$

Received Partial Payment \#21

Received Partial Payment \#22

Received Partial Payment \#23

Received Partial Payment \#24

Received Partial Payment \#25

Received Partial Payment \#26

Received Partial Payment \$27

Received Partial Payment \#28

Received Partial Payment \#29

Received Partial Payment \#30

Received Partial Payment \#31

Received Partial Payment \#32

Received Partial Payment \#33

Received Partial Payment \#34

Received Partial Payment \#35

Received Partial Payment \#36

Received Partial Payment \#37

Received Partial Payment \#38

Received Partial Payment \#39

Received Partial Payment \#40
$\$ 42,546.02$

$\$ 31,033.36$

$\$ 88,750.19$

$\$ 136,158.01$

$\$ 141,059.41$

$\$ 134,352.14$

$\$ 180,222.32$

$\$ 105,277.53$

$\$ 133,262.15$

$\$ 136,377.95$

$\$ 145,041.33$

$\$ 141,760.19$

$\$ 158,996.70$

$\$ 160,797.18$

$\$ 169,462.81$

$\$ 257,501.11$

$\$ 153,647.72$

$\$ 227,310.96$

$\$ 85,943.67$

$\$ 95,715.13$

$\$ 170,979,97$

$\$ 189,012.83$

$\$ 99,461.10$

$\$ 293,991.42$

$\$ 189,243.95$

$\$ 84,685.59$

$\$ 155,606.85$

$\$ 242,726.42$

$\$ 197,369.61$

$\$ 192,127.73$

$\$ 140,427.83$

$\$ 47,127.75$

$\$ 280,763.89$

$\$ 136,063.85$

$\$ 445,501.75$

$\$ 277,960.61$

$\$ 202,802.95$.

$\$ 355,814.24$

$\$ 65,463.76$

$\$ 161,154.00$ 
MCLR Program Status

as of 31 December 1995

\section{Approved Final Reports on MCLR Research Projects}

DOE/CE/23810-5 Project 650-50200: Chemical and Thermal Stability of Refrigerants and Lubricants with Metals, dated October 1992. The report was approved and distributed on 3 May 1993. (RDB3608)

DOE/CE/23810-6 Project 650-50300: Miscibility of Refrigerants with Lubricants, Part 1, dated October 1992. The report was approved and distributed in 17 May 1993. (RDB3503)

DOE/CE/23810-7 Project 650-50900: Theoretical Evaluations of R-22 Alternatives, dated January 1993. The report was approved and distributed on 27 May 1993. (RDB3305)

DOE/CE/23810-10 Project 655-51500: Accelerated Screening Methods for Determining Chemical and Thermal Stability of Refrigerant-Lubricant Mixtures, Part 1, dated April 1993. The report was approved and distributed on 10 August 1993. (RDB3501)

DOE/CE/23810-13 Project 650-50400: Compatibility of Refrigerants and Lubricants with Motor Materials, dated May 1993. The report was approved and distributed on 9 August 1993. (RDB3857, RDB3858, and RDB3859)

DOE/CE/23810-14 Project 650-50500: Compatibility of Refrigerants and Lubricants with Elastomers, dated January 1994. The report was approved and distributed on 15 March 1994. (RBD4501)

DOE/CE/23810-15 Project 650-50600: Compatibility of Refrigerants and Lubricants with Engineering Plastics, dated December 1993. The report was approved and distributed on 30 December 1993. (RDB4103)

DOE/CE/23810-16 Project 650-50800: Thermophysical. Properties of $R-32, R-123, R-124$ and $R-125$, dated April 1993. The report was approved and distributed on 10 August 1993. (RDB3860)

DOE/CE/23810-17 Project 655-51700: EHD Enhancement of Pool and In-Tube Boiling of Alternative Refrigerants, dated August 1993. The report was approved and distributed on 27 August 1993. (RDB3A16) .

DOE/CE/23810-18 Project 650-50300: Miscibility of Refrigerants with Lubricants, dated July 1993. The report was approved and distributed on 5 April 1994. (RDB4502) 
DOE/CE/23810-21 Project 655-51300: Accelerated Test Methods for Predicting the Life of Motor Materials Exposed to Refrigerant/Lubricant Mixtures, Phase 1, dated August 1993. The report was approved and distributed on 29 September 1993. (RDB3A17)

DOE/CE/23810-34 Project 655-51200: Solubility, Viscosity and Density of Refrigerant/ Lubricant Mixtures, dated April 1994. The report was approved and distributed on 10 November 1994. (RDB4889)

DOE/CE/23810-35 Project 655-51600: Accelerated Screening Methods for Predicting Lubricant Performance in Refrigerant Compressors (Interim Report: 1 May 93 through 31 Dec 93), dated January 1994. The report was approved and distributed on 27 January 1994. (RDB4538)

DOE/CE/23810-39 Project 650-50800: Thermophysical Properties of HFC-143a and HFC$152 a$, dated July 1994. The report was approved and distributed on 24 October 1994. (RDB4B09)

DOE/CE/23810-41 Final Report, Project 655-51500: Accelerated Screening Methods for Chemical and Thermal Stability, Part 2, dated December 1995. The report was approved 11 December 1995.

DOE/CE/23810-45 Project 655-51600: Accelerated Screening Methods for Predicting Lubricant performance in Refrigerant Compressors, dated November 1994. The report was approved and distributed on 9 December 1994. (RDB5109)

DOE/CE/23810-46 Final Report, Project 655-51400: Viscosity, Density and Gas Solubility of Refrigerant Azeotropes and Blends in Selected Refrigerant Lubricants, dated May 1995. The report was approved and distributed on 31 May 1995. (RDB5603)

DOE/CE/23810-47 Project 660-52700: Documentation of Newly Developed Methods to Assess Material Compatibility in Refrigerant and Air-Conditioning Applications, dated August 1994. The report was approved.

DOE/CE/23810-50 Final Report, Project 660-52400: Methods Development. for Measuring and Classifying Flammability/Combustibility of Refrigerants, dated December 1994. The report was approved and distributed on 18 October 1995. (RDB5A18)

DOE/CE/23810-54 Final Report, Project 655-51100: Sealed Tube Comparisons of the Compatibility of Desiccants with Refrigerants and Lubricants, dated May 1995. The report was approved and distributed on 14 September 1995. (RDB5932) 
MCLR Program Status

as of 31 December 1995

DOE/CE/23810-57 Interim Report, Project 655-51300: Accelerated Test Methods for Life Prediction of Hermetic Motor Insulating Systems Exposed to Alternative Refrigerant/Lubricant Mixtures, Phase 2: Proof-of-Concept Demonstration, dated April 1995. The report was approved and distributed on 12 June 1995. (RDB5649)

DOE/CE/23810-58 Interim Report, Project 660-52401: Lean Flammability Limit as a Fundamental Refrigerant Property, dated March 1995. The report was approved and distributed on 8 May 1995. (RDB5601)

DOE/CE/23810-60 Interim Report, Project 665-53300: HFC-245ca as a Low Pressure Refrigerant - Task 1, dated May 1995. The report was approved and distributed on 7 July 1995. (RDB5801) 


\section{Symposia, Conferences and Technical Paper Publications}

Presented at the 1992 ASHRAE Annual Meeting (27 Jun - 1 Jul 92), Baltimore, MD:

M. Menzer (ARI): Material Compatibility with New Refrigerants: What Do We Know?

Presented at the 1992 Purdue International Refrigeration Conference (14-17 Jul 92), West Lafayette, IN, and published in the Proceedings of the 1992 International Refrigeration Conference - Energy Efficiency and New Refrigerants, Volume II, Purdue University, West Lafayette, IN, July 1992:

M. Menzer (ARTI): ARTI Preliminary Compatibilities Results of Materials Exposed to Refrigerants and Lubricants, page 677.

D.F. Huttenlocher (Spauschus Associates, Inc.): Chemical and Thermal Stability of Refrigerant/Lubricant Mixtures with Metals, page 679.

M.B. Pate, S. Zoz, and L. Berkenbosch (Iowa State University of Science and Technology): Miscibility of Lubricants with Refrigerants, pages 681-686.

R.H. Seiple and G. Hamed (University of Akron): Compatibility of Refrigerants and Lubricants with Elastomers, pages 687-688.

R.C. Cavestri (Imagination Resources, Inc.): The Compatibility of Refrigerants and Lubricants with Engineering Plastics, page 689.

R. Doerr, D. Ernst, F. Howard and S. Kujak (The Trane Company):

Compatibility of Refrigerants and Lubricants with Motor Materials, p 691-692.

Presented at the 1992 Stator Manufacturing Technology Conference (31 Aug - 2 Sep 92), Nashville, TN:

R. Doerr (The Trane Company): Compatibility of Refrigerants and Lubricants with Motor Materials.

Presented at the 1992 International CFC and Halon Alternatives Conference (29 Sep 1 Oct 92), Washington, DC and published in The Proceedings of the 1992 International CFC and Halon Alternatives Conference - Stratospheric Ozone Protection for the 90's, Frederick, MD, 1992:

S. Szymurski (ARTI): Materials Compatibility and Lubricant Research on CFC-Refrigerant Substitutes - Research Update, pages 73-82.

J. Calm, Engineering Consultant: Refrigerant Database, pages 65-72. 
Presented at the 1993 ASHRAE Winter Meeting (23-27 Jan 93), Chicago, II, as part of a Seminar on Materials Compatibility and Lubricants Research - Alternative Refrigerants:

D. Huttenlocher (Spauschus Associates, Inc.): Chemical and Thermal Stability of Refrigerant-Lubricant Mixtures With Metals.

S. Zoz (Iowa State University of Science and Technology): Miscibility of Lubricants with Refrigerants.

G. Hamed (University of Akron): Compatibility of Refrigerants and Lubricants with Elastomers.

R. Cavestri (Imagination Resources, Inc.): Compatibility of Refrigerants and Lubricants with Engineering Plastics.'

R. Doerr (The Trane Company): Compatibility of Refrigerants and Lubricants with Motor Materials.

Presented and published in the Proceedings of the International Seminar on New Technology of Alternative Refrigerants (8-10 Feb 93), Japanese Association of Refrigeration, Tokyo, Japan, 1993:

R. Emst (The Trane Company): Compatibility of Hermetic Motor Materials with Alternative Refrigerants and Lubricants, page 109.

R. Cavestri (Imagination Resources, Inc.): Compatibility of Refrigerants and Lubricants with Engineering Plastics, page 109.

Presented at the Spring convention of the Southwest Chapter of the Electrical Apparatus Service Association (EASA) (1-3 Apr 93), Shreveport, LA:

Dr. R. Doerr (The Trane Company) presented a technical paper by R. Doerr, D. Emst and S. Kujak: Compatibility of Refrigerants and Lubricants with Motor Materials.

Presented at the 1993 ASHRAE Annual Meeting (26-30 Jun 93), Denver, CO:

P. Domanski and D. Didion (NIST): Thermodynamic Evaluation of $R-22$ Alternatives.

R. Cavestri (Imagination Resources, Inc.): Tensile Loss in Engineering Plastics: Chemical vs. Thermal Effects. 
Published in the ASHRAE Journal, Volume 35, No. 8, Atlanta, GA, Aug 93:

R. Doerr and S. Kujak (The Trane Company): Compatibility of Refrigerants and Lubricants with Motor Materials, pages 42-47.

G. Hamed and R. Seiple (University of Akron): Compatibility of Elastomers with Refrigerant/Lubricant Mixtures, pages 173-176.

Presented at the ASHRAE/NIST Refrigerants Conference, R-22/R-502 Alternatives (19-20 Aug 93) Gaithersburg, MD:

D. Ernst (The Trane Company): Materials Compatibility and Lubricants Research with Alternative Refrigerants.

Presented at the 1993 International CFC and Halon Alternative Conference (20 - 22 Oct 93), Washington, DC:

S. Szymurski (ARTI): Research Update: ARTI Materials Compatibility and Lubricant Research (MCLR) Program.

Presented at the Electrical Electronics Insulation Conference (EEIC) (Oct 93), Rosemount, IL:

R. Doerr and S. Kujak (The Trane Company): Compatibility of Alternative Refrigerants with Varnished Magnet Wire.

Published in the ASHRAE Journal, Volume 35, No. 11, Atlanta, GA, Nov 93:

James M. Calm, Engineering Consultant: Status and Use of the Refrigerant Database, pages 50-55.

Presented at the 1994 ASHRAE Winter Meeting (23 - 26 Jan 94), New Orleans, LA:

P. Ellis II (Radian Corporation): Conceptual Design for an Improved Hermetic Motor Insulation Test.

R. Kauffman (University of Dayton Research Institute): Accelerated Screening Methods for Determining Chemical and Thermal Stability of RefrigerantLubricant Mixtures.

C. Cusano (University of Ilinois): Comparison of Wear Data Obtained From a Falex Tester and a High Pressure Tribometer. 
Presented at and published in the Proceedings of the 45th Annual International Appliance Technical Conference (9-11 May 94), University of Wisconsin-Madison, Madison, WI:

R. Cavestri (Imagination Resources, Inc): Compatibility of Refrigerants and Lubricants with Engineering Plastics, pages 349-360.

R. Doerr and S. Kujak (The Trane Company): Compatibility of Refrigerants and Lubricants with Hermetic Motor Materials, pages 493-504.

J. Field (Spauschus Associates, Inc.): Sealed Tube Comparisons of the Compatibility of Desiccants with Refrigerants and Lubricants, pages 361-374.

S. Szymurski (ART): Research Update: Materials Compatibility and Lubricants Research (MCLR) Program, pages 387-398.

Presented at and published in the Proceedings of the 1994 International Refrigeration Conference at Purdue (19-24 Jul 94), West Lafayette, IN:

R.C. Cavestri (Imagination Resources, Inc.): Viscosity, Density and Gas Solubility of Refrigerant Blends and Azeotropes in Selected Refrigerant Lubricants, pages $425-430$.

D.R. Henderson (Spauschus Associates, Inc.): Solubility, Viscosity and Density of Refrigerant/Lubricant Mixtures, pages 419-424.

S. Kujak, T. Waite (The Trane Company): Compatibility of Motor Materials with Polyolester Lubricants: Effects of Moisture and Weak Acids, p 425-430. (Presented by Dr. Robert Doerr).

S.C. Zoz and M.B. Pate (Iowa State University): Critical Solubility Temperatures for Ten Different Non-CFC Refrigerants with Fourteen Different Lubricants, pages 431-436. (Published, but not presented).

J.M. Calm, Engineering Consultant: Information on Alternative Refrigerants: Status of the Refrigerant Database, pages 443-448.

Presented and published in the Proceedings of the International Symposium on R22 \& R502 Alternative Refrigerants '94 (8 - 9 December 1994), Kobe, Japan:

S.R. Szymurski (Air-Conditioning and Refrigeration Institute): Materials Compatibility and Lubricants Research (MCLR) Program, pages 94-99. 
Presented at the ARI Alternative Refrigerants Evaluation Program (AREP) Technical Committee Meeting (27 Jan 95), Chicago, II:

F. Biancardi (United Technologies Research Center): Investigation Into the Fractionation of Refrigerant Blends.

R. Tapscott (New Mexico Engineering Research Institute): Methods Development for Measuring and Classifying Flammability/Combustibility of Refrigerants.

Presented at the 1995 ASHRAE Winter Meeting, Chicago, IL (28 Jan 95 - 1 Feb 95):

Seminar 28 - Novel Experimental Techniques for Alternative Refrigerant-Lubricant Screening

C. Cusano (University of Illinois, Urbana): Predicting Lubricant Performance in Refrigerant Compressors by means of Bench Testers.

R. E. Kauffman (University of Dayton Research Institute): Accelerated Screening Methods for Determining Chemical and Thermal Stability of Refrigerant-Lubricant Mixtures.

P. E. Ellis II (Radian Corporation): Improved Hermetic Motor Insulation Life Test - Proof of Concept.

Seminar 21 - Materials Compatibility Update

R. Doerr (The Trane Company): Compatibility of Motor Materials with Alternative Refrigerants and Lubricants Under Retrofit Conditions.

Presented at the 1995 Meeting of the Mobile Air Conditioning Society, (28 Jan 95) New Orleans, LA:

M. W. Able (Integral Sciences, Inc.): Flushing Solvent Criteria for Mobile Air Conditioning Systems.

Presented at the 1995 ASHRAE Annual Meeting, San Diego, CA (25 - 28 June 1995):

Seminar 16 - Current Experience with Refrigerant Lubricants:

R. C. Cavestri (Imaginations Resources Inc.): Viscosity, Density, and Gas Solubility of $R-407 C$ in Selected 32 ISO VG POE Lubricants. 
Seminar 26 - New Knowledge in System Chemistry and Contaminant Control:

R. Doerr (The Trane Company): Compatibility of R-245ca with Motor Materials Under Retrofit Conditions.

Presented and published in the Proceedings of the 19th International Congress of Refrigeration (The Hague, Netherlands, $20-25$ Aug 95), International Institute of Refrigeration, Paris, France, 1995:

M. Menzer (ARI), W. Noel (DOE), and S. Szymurski (ARI): Lessons Learned from the ARTI Materials Compatibility and Lubricants Research Program, Volume IVa, pages 412-417.

Presented and published in the Procedings of the International CFC and Halon Alternatives Conference (Washington, DC, 21 - 23 Oct 95), Alliance for Responsible Atmospheric Policy, 1995:

H. Harvey Michels (United Technologies Research Center): Solubility Modeling of Refrigerant/Lubricant Mixtures, pages 49-58.

Jay Field (Spauschus Associates, Inc.): Sealed Tube Comparisons of the Compatibility of Desiccants with Refrigerants and Lubricants, pages 149-158.

Robert Doerr (The Trane Company): Compatibility of Refrigerants and Lubricants with Motor Materials Under Retrofit Conditions, pages 159-168.

James M. Calm (Engineering Consultant): Refrigerant and Lubricants - Data for Screening and Application, pages 169-178. 


\section{Project Summaries}

\section{0-50000 Refrigerant Database (Phase I)}

7 Feb 92 Contract signed with James M. Calm, Engineering Consultant.

13 Feb 92 Technical review conducted for MCLR Advisory Committee.

Feb 92 Initial distribution of database was made.

Apr 92 Quarterly update of the database was distributed.

Aug 92 Quarterly update of the database was distributed.

29 Sep 92 Technical presentation made at International CFC and Halon Alternatives Conference, Washington, DC.

Nov 92 Quarterly update of the database was distributed.

22 Feb 93 Quarterly update of the database was distributed and the final payment made under Phase I.

650-50200 Chemical and Thermal Stability of Refrigerants and Lubricant with Metals

-16 Jan 92 Contract signed with Spauschus Associates, Inc. (SAI)

Principal Investigator: Dietrich F. Huttenlocher, $\mathrm{PhD}$.

23 Apr 92 Technical progress review conducted at SAI, Atlanta, GA.

29 May 92 ARTI issued modification 1 to contract.

17 Jul 92 Technical presentation made at Purdue International Refrigerants Conference.

26 Jan 93 Technical presentation made at ASHRAE Winter meeting, Chicago, II.

15 Apr 93 Final payment made to the contractor.

3 May 93 Final report (DOE/CE/23810-5, Oct 92) approved and distributed.

650-50300 Miscibility of Refrigerants with Lubricants

6 Feb 92 Contract signed with Iowa State University of Science and Technology. Principal Investigator: Michael B. Pate, $\mathrm{PhD}$.

16 Apr 92 Technical progress review conducted at Iowa State University of Science and Technology, Ames, IA.

17 Jul 92 Technical Presentation made at Purdue International Refrigerants Conference.

12 Oct 92 Contract modification 1 signed authorizing Part 2.

26 Jan 93 Technical presentation made at ASHRAE Winter meeting, Chicago, IL.

17 May 93 Part 1 report (DOE/CE/23810-6, Oct 92) approved and distributed.

21 Jul 93 Contract modification 2 signed: no-cost extension of Part 2 through 30 Sep 93.

22 Feb 94 Final payment made to the contractor.

5 Apr 94 Final report (DOE/CE/23810-18, Jul 93) approved and distributed.

Jul 94 Technical paper published in the Proceedings of the 1994 International Refrigeration Conference at Purdue. 
650-50400 Compatibility of Refrigerants and Lubricants with Motor Materials

24 Feb 92 Contract signed with The Trane Company.

Principal Investigator: Robert Doerr, $\mathrm{PhD}$.

15 Apr 92 Technical progress review conducted at The Trane Company, La Crosse, WI.

29 Apr 92 Modification 1 to contract signed.

17 Jul 92 Technical presentation made at Purdue International Refrigerants Conference.

Sep 92 Technical presentation made at the Stator Manufacturing Technology Conference, Nashville, TN.

26 Jan 93 Technical presentation made at the ASHRAE Winter meeting in Chicago, IL.

Apr 93 Technical presentation made at the Spring Convention of the Southwest Chapter of the Electrical Apparatus Service Association, Shreveport, LA.

21 Jun 93 Final payment made to contractor.

28 Jul 93 Final report (DOE/CE/23810-13, May 93) approved.

Aug 93 Technical paper published in the Aug 93 issue of the ASHRAE Journal.

9 Aug 93 Final report (DOE/CE/23810-13, May 93) distributed.

Oct 93 Technical presentation made at the Electrical Electronics Insulation Conference, Rosemount, II.

11 May 94 Technical presentation made at the 45th Annual International Appliance Technical Conference, Madison, WI.

Jul 94 Technical presentation made at the International Refrigeration Conference at Purdue.

650-50500 Compatibility of Refrigerants and Lubricants with Elastomers

22 Jan 92 Technical oversight subgroup visit to University of Akron.

21 Feb 92 Contract signed with University of Akron.

Principal Investigator: Robert $\mathrm{H}$. Seiple.

6 May 92 Technical progress review conducted at the University of Akron, Akron, OH.

$17 \mathrm{Jul} 92$ Technical presentation made at the Purdue International Refrigerants Conference.

26 Jan 93 Technical presentation made at the ASHRAE Winter meeting, Chicago, II.

Aug 93 Technical paper published in the Aug 93 issue of the ASHRAE Journal.

24 Feb 94 Final payment made to the contractor.

15 Mar 94 Final report (DOE/CE/23810-14, Jan 94) approved and distributed. 
MCLR Program Status

as of 31 December 1995

650-50600 Compatibility of Refrigerants and Lubricants with Engineering Plastics

21 Jan 92 Pre-award on-site technical review conducted at Imagination Resources Inc., Dublin, $\mathrm{OH}$.

1 Mar 92 Contract signed with Imagination Resources, Inc. Principal Investigator: Richard C. Cavestri, $\mathrm{PhD}$.

5 May 92 Technical progress review conducted at Imaginations Resources, Inc., Dublin, OH.

17 Jul 92 Technical presentation made at the Purdue International Refrigerants Conference.

19 Nov 92 Modification 1 to contract signed.

26 Jan 93 Technical presentation made at the ASHRAE Winter meeting, Chicago, II.

$8 \mathrm{Feb} 93$ Technical presentation made at the International Seminar on New Technology of Alternative Refrigerants - Lubricants and Material Compatibility, Tokyo, Japan.

29 Jun 93 Technical presentation made at the ASHRAE Annual meeting, Denver, CO.

30 Dec 93 Final report (DOE/CE/23810-15, Dec 93) approved and distributed.

19 Jan 94 Final payment made to the contractor.

11 May 94 Technical presentation made at the 45th Annual International Appliance Technical Conference, Madison, WI.

\section{0-50800 Refrigerant Properties}

12 Mar 92 Contract signed with NIST. Principal Investigator: Richard F. Kayser, PhD.

17 Feb 93 Modification 1 to contract signed: addition of R-143a \& R-152a to work and project extended through 31 Dec 93.

15 Jun 93 Modification 2 to contract signed: no-cost extension through 31 Mar 94. Principal Investigator changed to $\mathrm{W}$. M. Haynes, $\mathrm{PhD}$.

$20 \mathrm{Jul} 93$ Final report on R-32, 123, 124, \& 125 (DOE/CE/23810-16, Apr 93) approved.

10 Aug 93 Final report on R-32, 123, 124, \& 125 (DOE/CE/23810-16, Apr 93) distributed.

1 Apr 94 Modification 3 to contract signed: no-cost extension through 30 Jun 94.

15 Sep 94 Final payment made to the contractor.

24 Oct 94 Final report on R-143a \& R-152a (DOE/CE/23810-39, Jul 94) approved and distributed.

650-50900 Theoretical Evaluations of R-22 Alternatives

$6 \mathrm{Jul} 92$ Contract signed with Building Environment Division, NIST.

Principal Investigator: David A. Didion, PhD.

21 Dec 92 Modification 1 to contract signed.

22 Feb 93 Final payment made to contractor.

27 May 93 Final report (DOE/CE-23810-7, Jan 93) approved and distributed.

28 Jun 93 Technical presentation made at the ASHRAE Annual meeting, Denver, CO. 


\section{5-50000 Refrigerant Database (Phase II)}

22 Oct 92 Amendment 1 to 650-50000 signed with James M. Calm, Engineering Consultant.

11 Nov 92 Amendment 2 to contract signed.

6 Jan 93 Amendment 3 to contract signed.

Apr 93 Quarterly update of database distributed.

Aug 93 Quarterly update of database distributed.

Nov 93 Quarterly update of database distributed.

Nov 93 Technical paper published in the Nov 93 issue of the ASHRAE Journal.

Nov 93 Quarterly update of database distributed.

22 Feb 94 Final payment made under Phase II.

655-50400 Compatibility of Motor Materials for Retrofits

4 Apr 94 Contract signed with The Trane Company.

Principal Investigator: Robert Doerr, $\mathrm{PhD}$.

7 Sep 94 Modification 1 to contract approved.

30 Jun 95 Modification 3 approved: no-cost extension through 30 Sep 95.

Jan 95 Technical presentation made at the ASHRAE Winter meeting, Chicago, II.

Jun 95 Technical presentation made at the ASHRAE Annual meeting, San Diego, CA.

Oct 95 Technical presentation made at the International CFC and Halon Alternatives Conference, Washington, DC.

655-51100 Compatibility of Desiccants with Refrigerants and Lubricants

27 Jul 93 Contract signed with Spauschus Associates, Inc.

Principal Investigator: Jay Field, $\mathrm{PhD}$.

24 Aug 93 On-site technical review conducted at Spauschus Associates, Inc., Stockbridge, GA.

11 May 94 Technical presentation made at the 45th Annual International Appliance Technical Conference, Madison, WI.

4 Oct 94 Modification 1 approved: no-cost extension through 31 Dec 94.

22 Jun 95 Final payment made to the contractor.

14 Sep 95 Final report (DOE/CE/23810-54, May 95) approved and distributed.

655-51200 Viscosity, Solubility and Density Measurements of Refrigerant-Lubricant Mixtures

1 Oct 92 Contract signed with Spauschus Associates Inc.

Principal Investigator: David Henderson, P.E.

8 Dec 92 On-site technical review conducted at Spauschus Associates, Inc., Atlanta, GA.

21 Dec 93 Modification 1 signed: no-cost extension through $31 \mathrm{Jul} 94$.

13 Jun 94 Final payment made to the contractor.

Jul 94 Technical presentation made at the International Refrigerant Conference at Purdue.

16 Aug 94 Final report (DOE/CE/23810-34, Apr 94) approved.

10 Nov 94 Revision to final report (DOE/CE/23810-34, Apr 94) distributed. 


\section{MCLR Program Status}

as of 31 December 1995

655-51300 Accelerated Test Methods for Predicting the Life of Motor Materials

5 Nov 92 Contract signed with Radian Corporation.

Effective date 30 Oct 92.

Principal Investigator: Peter F. Ellis, II.

14 Jan 93 On-site technical review conducted at Radian Corporation, Austin, TX.

26 Aug 93 Phase 1 report (DOE/CE/23810-21, Aug 93) approved.

29 Sep 93 Phase 1 report (DOE/CE/23810-21, Aug 93) distributed.

Jan 94 Technical presentation made at the ASHRAE Winter meeting, New Orleans, LA.

24 Mar 94 Modification 1 signed: Phase 2 authorization.

Principal Investigator: Karen T. Fuentes.

27 Sep 94 On-site technical review conducted at Radian Corporation, Austin TX.

30 Sep 94 Modification 2 approved: no-cost extension through 31 Mar 95.

Jan 95 Technical presentation made at the ASHRAE Winter meeting, Chicago, $\mathbb{I L}$.

12 Jun 95 Phase 2 report (DOE/CE/23810-57, Apr 95) approved and distributed.

16 Aug 95 Final payment made under Phase II of MCLR: Project was continued under Phase IV.

655-51400 Viscosity and Solubility Measurements of Refrigerant Blends and Lubricants

16 Oct 92 Pre-award on-site technical review conducted at Imagination Resources, Inc., Dublin, $\mathrm{OH}$.

7 Dec 92 Contract signed with Imagination Resources Inc.

Effective date 1 Dec 92.

Principal Investigator: Richard C. Cavestri, PhD.

9 Dec 92 On-site technical review conducted at Imagination Resources, Inc., Dublin, OH.

Jul 94 Technical presentation made at the International Refrigeration Conference at Purdue.

3 Feb 95 Draft final report (DOE/CE/23810-46, Aug 94) received.

31 May 95 Final report (DOE/CE/23810-46, May 95) approved.

Jun 95 Technical presentation made at the ASHRAE Annual meeting, San Diego, CA.

14 Jun 95 Final payment made to the contractor. 
655-51500 Accelerated Screening Methods for Determining Chemical and Thermal Stability

16 Oct 92 Contract signed with the University of Dayton Research Institute (UDRI). Effective date 15 Oct 92.

Principal Investigator: Robert E. Kauffman.

14 Nov 92 On-site technical review conducted at the UDRI, Dayton, OH.

12 May 93 Part 1 report (DOE/CE/23810-10, Apr 93) approved.

10 Aug 93 Part 1 report (DOC/CE/23810-10, Apr 93) distributed.

Jan 94 Technical presentation made at the 1994 ASHRAE Winter meeting.

31 Jan 94 No-cost extension of contract through 31 May 94 approved.

Nov 94 Initial draft final report (DOE/CE/23810-41, Jun 94) received.

Jan 95 Technical presentation made at 1995 ASHRAE Winter meeting, Chicago, II.

$24 \mathrm{Jul} 95$ First revised draft final report received.

18 Sep 95 Second revised draft final report received.

11 Dec 95 Final report (DOE/CE/23810-41, Dec 95) approved.

31 Jan 96 Final payment made to the contractor.

655-51600 Accelerated Screening Methods for Predicting Lubricant Performance

4 Nov 92 Contract signed with the University of Illinois at Urbane-Champaign.

Effective date 21 Aug 92.

Principal Investigator: Cristino Cusano, $\mathrm{PhD}$.

12 Nov 92 On-site technical review conducted at the University of Illinois at Urbana-Champaign.

Jan 94 Technical presentation made at the ASHRAE Winter meeting, New Orleans, LA.

27 Jan 94 Interim report on Part 1 (DOE/CE/23810-35, Jan 94) approved and distributed.

9 Dec 94 Final report (DOE/CE/23810-45, Nov 94) approved and distributed.

22 Dec 94 Final payment made to the contractor.

Jan 95 Technical presentation made at the ASHRAE Winter meeting, Chicago, II.

655-51700 Electrohydrodynamic (EHD) Enhancement of In-Tube Boiling of Alternative Refrigerants

6 Nov 92 Contract signed with the University of Maryland.

Effective date 1 Oct 92.

Principal Investigator: Michael M. Ohadi, PhD.

26 Aug 93 Final payment made to the contractor.

27 Aug 93 Final report (DOE/CE/23810-17, Aug 93) approved and distributed.

660-50000 Refrigerant Database (Phase III)

5 Nov 93 Contract signed with James M. Calm, Engineering Consultant.

May 94 Quarterly update of database distributed.

Jul 94 Technical presentation made at the International Refrigeration Conference at Purdue.

Aug 94 Quarterly update of database distributed.

22 Feb 95 Final payment made under Phase III. Project was continued under Phase IV. 
MCLR Program Status

as of 31 December 1995

660-50001 Refrigerant Toxicity Survey

2 May 94 Contract signed with James M. Calm, Engineering Consultant.

28 Feb 95 final payment made to contractor.

23 Aug 95 No-cost extension through 31 Dec 95 approved.

660-50800 Thermophysical Properties of Alternative Refrigerants (Phase III)

14 Mar 94 Contract signed with NIST, Thermophysical Division, Boulder, CO. Principal Investigators: W.M. Haynes, $\mathrm{PhD}, \&$ Mark O. McLinden, $\mathrm{PhD}$.

23 Feb 95 Modification 1 approved: no-cost extension through 31 Mar 96.

660-52000 Compatibility of Manufacturing Process Fluids with HFC Refrigerants and Ester Lubricants

26 Jan 94 Technical review conducted in New Orleans, LA, in conjunction with the ASHRAE Winter meeting.

31 Jan 94 Contract signed with Imagination Resources, Inc. Principal Investigator: Richard C. Cavestri, $\mathrm{PhD}$.

18 May 94 On-site technical review conducted at Imagination Resources, Inc., Dublin, OH.

18 May 94 Draft final report for Part 1 (DOE/CE/23810-43) submitted.

25 May 95 Final report for Part 1 (DOE/CE/23810-43, Nov 94) approved.

15 May 95 Draft final report for Part 2 (DOE/CE/23810-55) received.

2 Nov 95 On-site technical review conducted at Imagination Resources, Inc, Dublin, $\mathrm{OH}$.

660-52200 Compatibility Problems Resulting From Products of Motor Burnouts

6 Jun 94 Contract signed with Lawrence Livermore National Laboratory (LLNL). Principal Investigator: Ruth Hawley-Fedder, $\mathrm{PhD}$.

13 Jun 95 Amendment 1 accepted by LLNL: extending the project through 31 Dec 95 and adding $\$ 77,000$.

660-52300 Investigation Into the Fractionation of Refrigerant Blends

23 Feb 94 On-site technical review conducted at United Technologies Research Center (UTRC), East Hartford, CT.

28 Mar 94 Contract signed with United Technologies Research Center.

Principal Investigator: Frank R. Biancardi.

27 Jan 95 Technical presentation made at the ARI Alternative Refrigerants Evaluation Program (AREP) Technical Committee meeting, Chicago, II.

2 Feb 95 Modification 1 approved: no-cost extension through 31 Mar 95.

14 Mar 95 Modification 2 approved: additional work and extension through 30 Nov 95.

15 Mar 95 On-site technical review conducted at UTRC, East Hartford, CT.

Oct 95 Technical presentation at the International CFC and Halon Alternatives Conference, Washington, DC. 
MCLR Program Status

as of 31 December 1995

660-52400 Methods Development for Measuring and Classifying

Flammability/Combustibility of Refrigerants

2 Mar 94 On-site technical review conducted at the New Mexico Engineering Research Institute (NMERD), Albuquerque, NM.

18 Mar 94 Contract signed with University of New Mexico.

Principal Investigator: Robert $\mathrm{E}$. Tapscott, $\mathrm{PhD}$.

24 Aug 94 On-site technical review conducted at NMERI, Albuquerque, NM.

3 Oct 94 Modification 1 approved: no-cost extension through 28 Feb 95.

27 Jan 95 Technical presentation made at the ARI Alternative Refrigerants Evaluation Program (AREP) Technical Committee meeting, Chicago, II.

29 Mar 95 Draft final report (DOE/CE/23810-50, Dec 94) received.

12 Oct 95 Final payment made to the contractor.

18 Oct 95 Final report (DOE/CE/23810-50, Dec 94) approved and distributed.

660-52401 Lean Flammability Limit as a Fundamental Refrigerant Property

28 Sep 94 Contract signed with NIST Building and Fire Research Lab.

Principal Investigator: William L. Grosshandler, $\mathrm{PhD}$.

8 May 95 Interim report Phase 1 (DOE/CE/23810-58, Mar 95) approved.

10 May 95 Modification 1 for Phase 2 signed.

660-52500 Investigation of Flushing and Clean-out Methods for Refrigeration

Equipment to Ensure System Compatibility

22 Jun 93 RFP solicitations mailed.

660-52501 Flushing and Clean-out Methods

19 Nov 93 Contract signed with Spauschus Associates, Inc.

Principal Investigator: Thomas L. Starr, $\mathrm{PhD}$.

15 Mar 94 Modification 1 to contract signed: no-cost extension through 31 Mar 94.

28 Mar 94 On-site technical review conducted at Spauschus Associates, Stockbridge, GA.

31 Mar 94 Draft interim report (DOE/CE/23810-36, Mar 94) accepted.

15 Jul 94 Final payment made to the contractor.

660-52502 Flushing and Clean-out Methods

11 Nov 93 Contract signed with Integral Sciences, Inc.

Principal Investigator: John J. Byrne.

29 Mar 94 On-site technical review conducted at Integral Sciences, Inc., Columbus, OH.

29 Apr 94 Final report for Part 1 (DOE/CE/23810-37, Apr 94) accepted.

24 Aug 94 Modification 1 for Part 2 awarded.

28 Jan 95 Technical presentation made at the meeting of the Mobile Air Conditioning Society, New Orleans, LA. 
660-52600 Effects of Lubricant Additives

14 Nov 94 Contract signed with Imagination Resources Inc., Dublin, $\mathrm{OH}$.

Principal Investigator: Richard C. Cavestri, $\mathrm{PhD}$.

26 Dec 95 Modification 1 signed: requirement for monthly progress status reports added at no addition cost to contract.

660-52700 Documentation of Newly Developed Methods to Assess Material

Compatibility in Refrigeration/Air-Conditioning Applications

In-house effort by ARTI.

660-54000 Infrared Analysis of Refrigerant Blends

19 Jul 95 Effective date of contract with Hope Technology Corp., Providence, RI.

Principal Investigator: Dr. Ted Morse.

19 Oct 95 Modification 1 to contract approved; no-cost extension through 31 Dec 95.

21 Dec 95 No-cost extension through 30 March 1996 approved.

665-50000 Refrigerant Database (Phase IV)

11 Nov 94 Effective date of contract for Phase IV effort.

Principal Investigator: James M. Calm, Engineering Consultant.

Feb 95 Quarterly update of database was released.

Jun 95 Quarterly update of database was released.

Oct 95 Quarterly update of database was released.

Oct 95 Technical presentation made at the International CFC and Halon Alternatives Conference, Washington, DC.

665-51300 Accelerated Test Methods for Life of Hermetic Motor Materials

29 Mar 95 Modification for Phase 3 of project signed.

Principal Investigator: Karen Fuentes

665-53000 System Contaminant Levels

6 Apr 95 On-site technical review conducted at Imagination Resources, Inc. Dublin, OH.

2 Jun 95 On-site technical review conducted at Imagination Resources, Inc. Dublin, OH.

5 Jul 95 Effective date of contract with Imagination Resources Inc., Dublin, OH.

Principal Investigator: Dr. Richard C. Cavestri.

665-53100 Lubricant Circulation

28 Feb 95 Effective date of contract with United Technologies Corp.

Principal Investigator: Frank R. Biancardi

14 Mar 95 On-site technical review conducted at the United Technologies Research Center, East Hartford, CT. 
MCLR Program Status

as of 31 December 1995

665-53200 Study of Foaming Characteristics

8 Jun 95 Pre-award on-site technical review conducted at the University of Florida, Gainsville, FL.

26 Oct 95 Contract signed by the University of Florida.

Effective project start date is 19 Oct 95.

665-53300 Evaluation of HFC-245ca as a Low Pressure Refrigerant

31 Jan 95 Effective date of contract with The Trane Company.

Principal Investigator: Paul Glamm.

7 Jul 95 Interim report for Part 1 (DOE/CE/23810-60, May 95) approved and distributed.

24 Dec 95 Received draft final report (DOE/CE/23810-67). 


\section{DISCLAIMER}

This report was prepared as an account of work sponsored by an agency of the United States Government. Neither the United States. Government nor any agency thereof, nor any of their employees, makes any warranty, express or implied, or assumes any legal liability or responsibility for the accuracy, completeness, or usefulness of any information, apparatus, product, or process disclosed, or represents that its use would not infringe privately owned rights. Reference herein to any specific commercial product, process, or service by trade name, trademark, manufacturer, or otherwise does not necessarily constitute or imply its endorsement, recommendation, of favoring by the United States Government or any agency thereof. The views and opinions of authors expressed herein do not necessarily state or reflect those of the United States Government or any agency thereof. 
